\title{
Survival of Euvarroa sinhai Delfinado and Baker (Acari, Varroidae) on workers of Apis cerana Fabr, Apis florea Fabr and Apis mellifera $L$ in cages
}

\section{N Koeniger 1, G Koeniger 1, LI De Guzman 2, C Lekprayoon 3}

\author{
1 institut für Bienenkunde (Polytechnische Gesellschaft), Fachbereich Biologie \\ der JW Goethe-Universität Frankfurt am Main, Karl-von-Frisch-Weg 2, 61440 Oberursel 1, Germany; \\ 2 Dept of Entomology, Louisiana State University, Baton Rouge, LA 70803, USA; \\ ${ }^{3}$ Bee Biology Research Unit, Dept of Biology, Faculty of Science, Chulalongkorn University, \\ Bangkok 10500, Thailand
}

(Received 4 December 1992; accepted 29 March 1993)

\begin{abstract}
Summary - Euvarroa sinhai was collected from drone brood cells of Apis florea and introduced into cages with 5 worker bees of 3 honeybee species. After $24 \mathrm{~h}$ the survival rates of the mites were determined. The survival of Euvarroa sinhai on Apis mellifera was $53 \%$ compared to $70 \%$ on Apis florea and $8 \%$ on Apis cerana. Surviving Euvarroa sinhai were found under abdominal sternites of the bees. Experiments under more natural conditions are required to further explore the question of whether or not Euvarroa sinhai must be considered as a new candidate for parasitism on the Western honeybee Apis mellifera.
\end{abstract}

host-parasite relation / Euvarroa sinhai / Apis mellifera / Apis cerana / Apis florea

\section{INTRODUCTION}

Varroa jacobsoni was restricted originally to one host species, the Asian honeybee Apis cerana. After introduction of the allopatric honeybee species Apis mellifera into the habitat of the Asian honeybees, Varroa jacobsoni rapidly invaded the imported colonies. Subsequently, Varroa jacobsoni has spread worldwide and has caused heavy losses to apiculturists. It is currently the economically most serious parasite of Apis mellifera. Euvarroa sinhai is naturally associated with Apis florea (Akratanakul and Burgett, 1976; Koeniger et al, 1983; Aggarwal and Kapil, 1988). Kapil and Aggarwal (1987) reported the occurrence of this mite species in the hive debris of Apis mellifera in India. More recently, Rath and Delfinado-Baker (1990) found one Euvarroa sinhai in the hive debris of Apis mellifera in Thailand. Further, Mossadegh (1990a,b) experimentally infested brood cells of Apis mellifera with Euvarroa sinhai and reported successful reproduction on the brood of Apis mellifera. Whether or not adult worker bees of differ- 
ent honeybee species can serve as host for Euvarroa sinhai is unknown.

\section{MATERIALS AND METHODS}

The experiments were conducted in Bangkok, Thailand in February 1992. Experimental bees were taken from brood combs of Apis cerana, Apis mellifera and from the brood area of Apis florea colonies. All colonies were kept at the campus of Chulalongkorn University. Hair curlers (diameter $1 \mathrm{~cm}$, height $5 \mathrm{~cm}$ ) made out of plastic mesh were used as test cages. The mesh $(5 \mathrm{~mm} \times 2 \mathrm{~mm}$ ) were not passable by bees of any species, whereas Euvarroa sinhai could easily move through. The upper end of the tube was covered with a cap which contained sugar candy (mixture of honey and powdered sugar). Each cage was set up with 5 bees of the particular test species. The bottom of each cage was placed in a small Petri dish $3 \mathrm{~cm}$ in diameter: experimental bees were then inoculated by passing a mite resting on a fine brush through the mesh of the cage so that it came into contact with a bee. We introduced 5 mites per cage; 8 cages per honey bee species and 5 for control (no bees). All test cages together with the Petri dish were then placed on a tray lined with petroleum jelly and maintained at $28^{\circ} \mathrm{C}-31^{\circ} \mathrm{C}$ and $60-85 \% \mathrm{RH}$. After $24 \mathrm{~h}$, the petroleum jelly was searched for mites. All test cages were transferred into a deep freezer $\left(-18^{\circ} \mathrm{C}\right)$ for $30 \mathrm{~min}$ to kill all bees and mites. Bees were examined under a dissecting microscope to determine the fate of introduced mites. Mites found on the bees (after freezing) were considered to be alive at the end of the experiment.

Before the experiment all mites were examined and only intact specimens were used. After the experiment, mites were examined again for injuries.

\section{RESULTS}

\section{Infestation rate}

We inspected 12 combs of Apis florea (12 different colonies) and at least 200 capped drone brood cells per comb were opened
Table I. Number of sealed Apis florea drone brood cells infested by Euvarroa sinhai.

\begin{tabular}{rrrl} 
Comb & Inspected cells & \multicolumn{2}{c}{ Infested cells } \\
\hline & & & \\
1 & 458 & 245 & $(53 \%)$ \\
2 & 350 & 26 & $(7 \%)$ \\
3 & 800 & 2 & $(0.2 \%)$ \\
4 & 700 & 2 & $(0.3 \%)$ \\
5 & 280 & 2 & $(0.7 \%)$ \\
6 & 600 & 1 & $(0.2 \%)$ \\
7 & 200 & 0 & \\
8 & 200 & 0 & \\
9 & 200 & 0 & \\
10 & 200 & 0 & \\
11 & 200 & 0 & \\
12 & 200 & 0 & \\
\hline
\end{tabular}

(table I). Only 6 combs were infested. With exception of 2 colonies the rate of Euvarroa sinhai infestation was less than $1 \%$.

\section{Behaviour of the bees towards inoculated Euvarroa sinhai}

During mite introduction, we noticed differences among the bee species: on Apis florea we rarely saw any significant reaction towards Euvarroa sinhai. The bees did not exhibit grooming or any other kind of increase in activity after the mites climbed on them. Also the mites moved readily from the brush to the bees as soon as the brush came into first contact with a passing bee. However, at the very moment they came into contact with Euvarroa sinhai, Apis cerana workers showed an intensive grooming reaction. The mites were brushed off by the legs. In some cases we noted that mites were removed from other bees. We observed bees seizing mites with their mandibles. Several mites feil to the bottom of the cage (into the Petri dish) from where they climbed onto the cage and to the next bee. However, after $1 \mathrm{~h}$, 
the first immobile mites were observed and some were already on the petroleum jelly surrounding the cage.

In Apis mellifera we did not notice increased grooming after mite introduction. We had difficulties in transferring Euvarroa sinhai mites from the brush to Apis mellifera workers. The mites often remained on the brush and did not move onto the bee during the contacts. About half of the mites left the bees after we initially had put them on. Several mites were observed wandering on the cage during the experiment.

\section{Survival of Euvarroa sinhai}

All of the mites transferred into empty cages were recovered after $24 \mathrm{~h}$ on the petroleum jelly, where they became stuck and consequently died (table II).

In Apis florea we found 28 mites on the frozen bees. They were concealed between the sternites of the abdomen (fig 1).

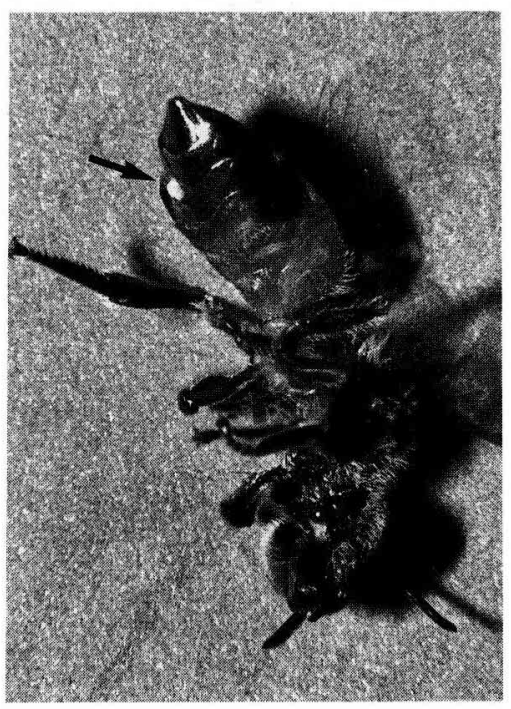

Fig 1. Apis florea worker carries Euvarroa sinhai under an abdominal sternite. The white spot is presumably faeces.
Twelve mites were collected dead from the petroleum jelly (table II).

In Apis mellifera 19 mites were recovered from the petroleum jelly and 21 mites were found on the bees (table II). Further, Euvarroa sinhai was detected under the sternites of the abdomen of the Apis mellifera worker bees (fig 2). In several cases we noticed white spots presumably of mite feces outside the mite's position (fig 3).

In Apis cerana cages only 3 Euvarroa sinhai were found on the bees. Thirtyseven mites were collected from the petroleum jelly. Thus this bee species successfully removed most of the mites and had significantly $\left(\chi^{2}=10.3, P<0.001\right)$ less surviving Euvarroa sinhai than the 2 other bee species (table II). Upon examination of the dead Euvarroa sinhai we found that 7 mites were mutilated (table II). One or more legs were amputated (fig 4). With Apis florea and Apis mellifera we did not detect any injuries of mites.

The 24-h survival rate of Euvarroa sinhai was best (70\%) on its natural host, Apis florea (table II). The survival rate on Apis mellifera was $\approx 53 \%$ and did not differ significantly $\left(\chi^{2}=2.6, P>0.05\right)$ from that of Apis florea. Apis cerana successfully eliminated most of the mites and had significantly $(P<$ 0.01) less surviving Euvarroa sinhai than the other honeybee species.

\section{DISCUSSION}

Mossadegh (1991) inspected 31 Apis florea colonies in Iran and found Euvarroa sinhai in every colony. He examined 8 combs with drone brood cells and found a mean infestation rate of $8 \%$. We checked 12 combs which contained capped drone brood cells. In 6 combs the drone brood was infested, but apart from 2 the percentage was less than $1 \%$. In the other 6 combs, we inspected about $50 \%$ of the 
Table II. Number of alive and dead Euvarroa sinhai $24 \mathrm{~h}$ after inoculation.

\begin{tabular}{|c|c|c|c|c|c|c|c|c|c|c|}
\hline & & \multicolumn{9}{|c|}{ Cage No } \\
\hline & & 1 & 2 & 3 & 4 & 5 & 6 & 7 & 8 & Sum \\
\hline \multirow[t]{2}{*}{ Control } & Mites alive & 0 & 0 & 0 & 0 & 0 & - & - & - & 0 \\
\hline & Mites dead & 5 & 5 & 5 & 5 & 5 & - & - & - & 25 \\
\hline \multirow[t]{2}{*}{ A florea } & Mites on bees & 2 & 5 & 4 & 2 & 4 & 4 & 4 & 3 & 28 \\
\hline & Mites dead & 3 & 0 & 1 & 3 & 1 & 1 & 1 & 2 & 12 \\
\hline \multirow{2}{*}{ A mellifera } & Mites on bees & 1 & 4 & 3 & 2 & 3 & 3 & 2 & 3 & 21 \\
\hline & Mites dead & 4 & 1 & 2 & 3 & 2 & 2 & 3 & 2 & 19 \\
\hline \multirow[t]{3}{*}{ A cerana } & Mites on bees & 0 & 0 & 0 & 0 & 0 & 2 & 0 & 1 & 3 \\
\hline & Mites dead & 5 & 5 & 5 & 5 & 5 & 3 & 5 & 4 & 37 \\
\hline & (Mites injured) & (1) & (2) & $(0)$ & (1) & (1) & (1) & (0) & (1) & (7) \\
\hline
\end{tabular}

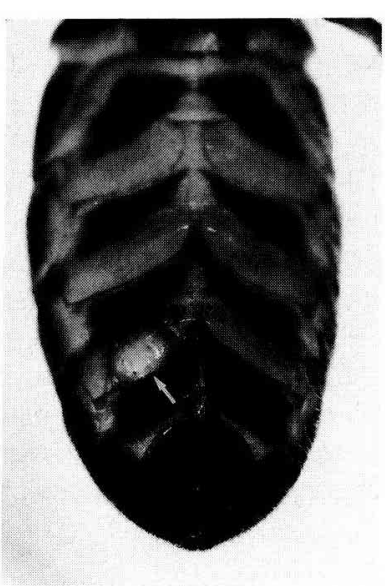

Fig 2. Euvarroa sinhai pulled out slightly from its original resting position under the abdominal sternite of an Apis mellifera worker bee.

drone cells without finding a single mite. So the rate of Euvarroa sinhai infestation of Apis florea colonies which we inspected in Thailand was probably lower than that in Southern Iran.

The question of whether Euvarroa sinhai has the potential to successfully para-

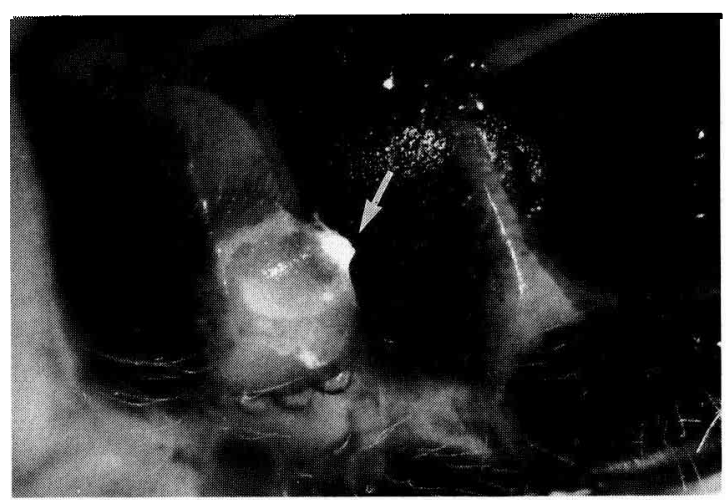

Fig 3. A white faecal drop of Euvarroa sinhai has been deposited outside its resting position indicating successful feeding on Apis mellifera.

sitize other honeybee species is of some interest. Naturally, Euvarroa sinhai is found in strict association with Apis florea. In many regions of Asia Apis florea lives sympatrically with the other Asian honeybee species. But there are no reports of Euvarroa sinhai from colonies of Apis cerana 

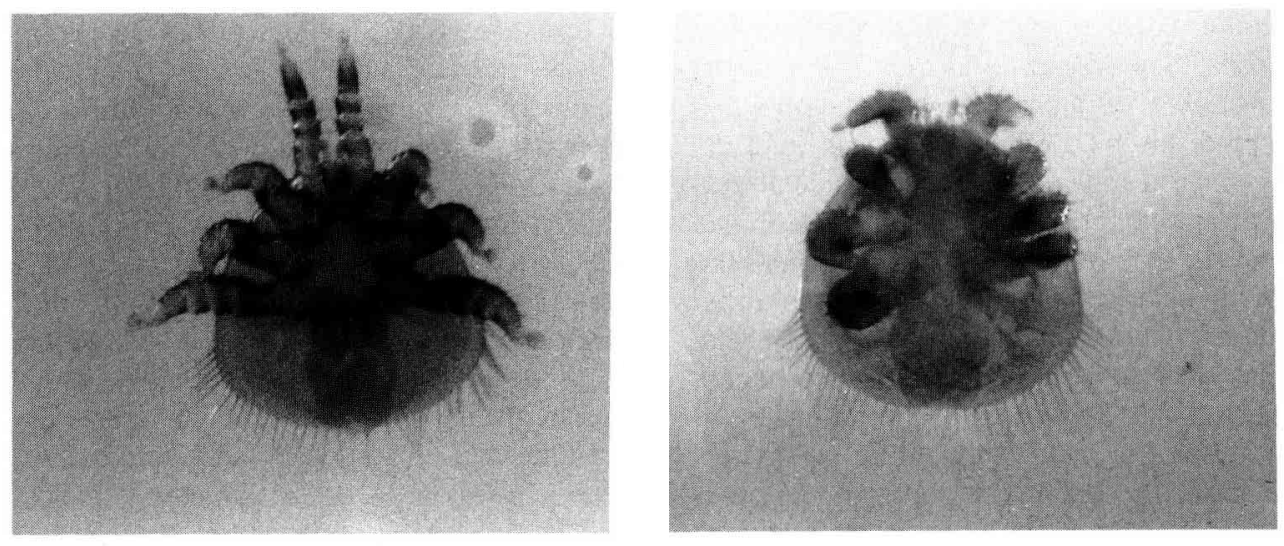

Fig 4. An injured Euvarroa sinhai (right) of Apis cerana and an intact mite (left).

Table III. Comparison of survival rates in cage experiments.

A florea A mellifera A cerana Control
(\%)
(\%)
(\%)
(\%)

Survival 70

53

8

0

and Apis dorsata (Koeniger and Koeniger, 1985). In Southern Iran the distributions of Apis florea and Apis mellifera overlap (Ruttner et al, 1985). However, Mossadegh (personal communication, 1992) did not find Euvarroa sinhai in Apis mellifera colonies.

The 2 reported findings of Euvarroa sinhai from colonies of Apis mellifera occurred in India (Kapil and Aggarwal, 1987) and northern Thailand (Rath and Delfinado-Baker, 1990). In both areas, Apis mellifera was successfully introduced. The dead mites were discovered in the hive debris of the Apis mellifera colonies.

Akratanakul (1976) and Mossadegh and Komeili (1986) pointed out the similarity between the life cycles of Euvarroa sinhai and Varroa jacobsoni. Consequently Mossadegh $(1990 a, b)$ demonstrated that Euvarroa sinhai can develop on worker and drone brood of Apis mellifera. In our cage experiments these mites were exposed to worker bees (nurse bees sampled from the brood area) of different honeybee species. Surely the cage and other experimental circumstances also had a major impact on the survival of mites, since only $70 \%$ survived on Apis florea. Further, mites wandering out of the cage were caught and died in the petroleum jelly. According to some preliminary experiments and observations, these effects seem to increase with the duration of the cage test. Therefore we restricted the test to $24 \mathrm{~h}$, which also had the advantage of avoiding bee mortality. Nevertheless we found clear differences among the honeybee species.

Although the mites were initially reluctant to move onto the bees, they were able to infest Apis mellifera workers and survive for $24 \mathrm{~h}$. The fecal droppings indicated that Euvarroa sinhai actively fed on the Apis mellifera workers. The success rate of mites was not significantly lower than on 
workers of their natural host species Apis florea. Since Apis florea was the smallest and Apis mellifera the largest honeybee tested, the size or the height of bees did not play a major role in mite survival, Euvarroa sinhai can feed on adults and also can develop on brood of Apis mellifera under special conditions. Experiments under more natural conditions (in small hives, etc) are therefore required and are necessary to further explore the question of whether Euvarroa sinhai must be considered as a potential new candidate for parasitism on the Western honeybee Apis mellifera. Apis cerana was most successful in the removal of Euvarroa sinhai. Peng et al (1987) obtained similar results when they exposed Apis cerana to Varroa jacobsoni. Apparently grooming behaviour is effective against both species of mites.

Résumé - Survie d'Euvarroa sinhai
Delfinado et Baker (Acari, Varroidae)
sur les ouvrières d'Apis cerana Fabr,
Apis florea Fabr et Apis mellifera L lors
d'expériences en cagettes. Dans la nature, Euvarroa sinhai n'est associé qu'à l'espèce hôte Apis florea (Akratanakul et Burgett, 1976; Koeniger et al, 1983; Aggarwal et Kapil, 1988). Kapil et Aggarwal (1987) ont pourtant rapporté la présence de cet acarien dans les débris des colonies d'A mellifera élevées en Inde. Plus récemment, Rath et Delfinado-Baker (1990) ont trouvé une femelle d'Euvarroa sinhai dans les débris d'A mellifera en Thaillande. Mossadegh (1990a et b) a infesté expérimentalement des cellules de couvain d'A mellifera avec Euvarroa sinhai et observé que l'acarien avait réussi à s'y reproduire. Ce travail cherche à répondre à la question : les ouvrières des diverses espèces d'Apis peuvent-elles servir d'hôte à Euvarroa sinhai ? Des abeilles ont été prélevées sur les zones de couvain de colonies d'abeilles des 3 espèces, cerana, mellifera et florea, élevées sur le campus de l'université de Chulalongkorn. Des bigoudis (diamètre $1 \mathrm{~cm}$, hauteur $5 \mathrm{~cm}$ ) en grillage en plastique ont été utilisés comme cagettes de test. Chaque cagette a été pourvue avec 5 abeilles de l'espèce testée. On a ensuite infesté les abeilles en faisant passer à travers le grillage de la cagette un acarien posé sur un pinceau fin, de façon à ce qu'il vienne en contact avec une abeille. Nous avons introduit 5 acariens par cagette à raison de 8 cagettes par espèce d'abeilles et de 5 cagettes témoin (pas d'abeilles). Les acariens transférés dans les cagettes vides (témoins) ont tous été retrouvés $24 \mathrm{~h}$ plus tard. Ils étaient collés sur la vaseline qui enduit le support autour des cagettes et étaient donc morts (tableau II). Dans les cagettes avec $A$ florea, nous avons trouvé sur les abeilles 28 acariens, qui étaient cachés entre les sternites de l'abdomen (fig 1). Douze acariens ont été retrouvés morts (tableau II). Dans les cagettes avec $A$ mellifera, 19 avariens ont été retrouvés dans la vaseline et 21 sur les abeilles, situés sous les sternites de l'abdomen des ouvrières (tableau II, fig 2). $\dot{A}$ plusieurs reprises, nous avons remarqué des points blancs, vraisemblablement des fécès d'acariens (fig 3). Dans les cagettes avec $A$ cerana, seuls 3 acariens ont été trouvés sur les abeilles, mais 37 dans la vaseline. Cette espèce parvient donc à se débarrasser de la plupart des acariens et a un nombre significativement moindre $\left(\chi^{2}=\right.$ $10,3, P<0,001)$ d'acariens survivants que les 2 autres espèces (tableau II). À l'examen des Euvarroa sinhai morts, nous avons trouvé 7 acariens mutilés (tableau II) avec une (fig 4) ou plusieurs pattes amputées. Ce phénomène n'a pas été observé avec $A$ florea, ni avec $A$ mellifera.

Mossadegh (1990a et b) a montré qu'Euvarroa sinhai pouvait se reproduire et se développer sur du couvain d'ouvrières et de mâles d'A mellifera. Dans nos expériences en cagettes, cet acarien a été ca- 
pable d'infester des ouvrières d'A mellifera et de survivre pendant $24 \mathrm{~h}$. Le taux de réussite a été un peu plus faible que sur les ouvrières de son hôte naturel $A$ florea. Les gouttelettes fécales indiquent qu'Euvarroa sinhai s'est nourri activement sur les ouvrières d' $A$ mellifera. Des expériences dans des conditions plus naturelles (dans des ruchettes, etc) sont nécessaires et conseillées pour élucider la question de savoir dans quelle mesure Euvarroa sinhai, en tant que "nouveau" parasite, représente un danger potentiel pour l'abeille occidentale A mellifera.

Euvarroa sinhai / Apis mellifera / Apis cerana / Apis florea / relation hôteparasite

\section{Zusammenfassung - Käfigversuche zur Überlebensrate von Euvarroa sinhai Delfinado und Baker auf Arbeiterinnen von Apis cerana, Apis florea und Apis mellifera. Euvarroa sinhai ist natürlicher- weise auf die Wirtsart Apis florea be- schränkt (Akratanakul und Burgett, 1976; Koeniger et al, 1983; Aggarwal und Kapil, 1988). Kapil und Aggarwal (1987) jedoch berichteten über das Vorkommen dieser Milbenart im Gemüll von in Indien gehalte- nen Apis mellifera Bienenvölkern. Kürzlich fanden auch Rath und Delfinado-Baker (1990) eine Euvarroa sinhai bei Apis mellif- era in Thailand.}

Mossadegh (1990a,b) konnte experimentell Brutzellen von Apis mellifera mit Euvarroa sinhai impfen und erfolgreiche Reproduktion beobachten. Ob auch Arbeiterinnen anderer Honigbienenarten als Wirt für Euvarroa sinhai in Frage kommen, soll mit dieser Arbeit geklärt werden.

Die Versuchsbienen wurden aus dem Brutbereich von Bienenvölker der Arten Apis cerana, Apis mellifera und Apis florea entnommen, die auf dem Campus der Chulalongkorn University in Bangkok ge- halten wurden. Lockenwickler (Durchmesser $1 \mathrm{~cm}$, Höhe $5 \mathrm{~cm}$ ) aus Plastikgewebe wurden als Testkäfige benutzt. In jedem Käfig waren fünf Bienen, die mit fünf $E u$ varroa sinhai infiziert wurden. Dazu wurden die Milben mit einem Pinsel aufgenommen und durch das Gitter des Käfigs mit den Bienen in Kontakt gebracht. Wir haben acht Käfige pro Bienenart und fünf leere Käfige als Kontrolle eingesetzt.

Die Milben verließen die leeren Käfige und wurden vollständig und tot auf der mit Vaseline bestrichenen Unterlage gefunden, die jeden Käfig lückenlos umgab (Tabelle II).

Bei Apis florea fanden wir 28 Milben auf den Bienen, wobei die Milben zwischen den Sterniten des Abdomens steckten (Abb 1). 12 Euvarroa sinhai waren tot (Tabelle II).

Bei Apis mellifera wurden 19 Milben tot auf der Vaseline gefunden und 21 auf den Bienen (Tabelle II, Abb 2). Bei mehreren Milben wurden weiße Exkremente bemerkt, die auf eine aktive Nahrungsaufnahle der Euvarroa sinhai an der Arbeiterin von Apis mellifera schließen lassen (Abb 3).

Bei Apis cerana wurden nur drei Milben auf den Bienen gefunden, die anderen 37 Euvarroa sinhai lagen tot auf der Vaseline. Damit waren bei dieser Bienenart signifikant $\left(\chi^{2}=10.3, P<0.001\right)$ weniger überlebende Milben vorhanden als bei den beiden anderen Bienenarten (Tabelle II). Weiter wurden bei Apis cerana verletzte Milben gefunden (Abb 4).

Mossadegh (1990a,b) hat nachgewiesen, daß Euvarroa sinhai erfolgreich auf Brut von Apis mellifera reproduzieren kann. In unseren Käfigversuchen waren diese Milben in der Lage, Arbeiterinnen von Apis mellifera zu befallen und für 24 Stunden zu überleben. Dabei war die Überlebensrate auf Apis mellifera nur wenig geringer als auf dem natürlichen 
Wirt Apis florea. Weiter deuten die abgesetzten Kottropfen auf eine erfolgreiche Nahrungsaufnahme von Euvarroa sinhai auf den Arbeiterinnen von Apis mellifera hin. Weitere Versuche zur Klärung der Frage, inwieweit Euvarroa sinhai als "neuer" Parasit eine mögliche Gefahr für Apis mellifera darstellt, sind empfehlenswert und notwendig.

\section{Euvarroa sinhai / Apis mellifera / Apis cerana / Apis florea / Parasit-Wirt Bezie- hung}

\section{REFERENCES}

Aggarwal K, Kapil RP (1988) Observations on the effect of queen cell construction on Euvarroa sinhai infestation in drone brood of Apis florea. In: Africanized Honey Bees and Bee Mites (Needham GR, Page RE, Delfinado-Baker M, Bowman CE, eds) Ellis Horwood Ser Entomology and Acarology, John Wiley and Sons, NY, 404-408

Akratanakul P (1976) Biology and systematics of bee mites of the family Varroidae. MS thesis, Oregon State University, Corvallis, OR, $64 \mathrm{pp}$

Akratanakul P, Burgett M (1976) Euvarroa sinhai Delfinado and Baker (Acarina: Mesostigmata): a parasitic mite of Apis florea. J Apic Res 15, 11-13

Kapil RP, Aggarwal K (1987) Euvarroa sinhai found in Apis mellifera hive debris. Bee World 68 (4), 189

Koeniger N, Koeniger G (1985) Change of host by parasitic mites in Asia after a new honey- bee species is introduced. In: Proc 3rd Int Cont Apic Trop Climates. Nairobi, 160-162

Koeniger $\mathrm{N}$, Koeniger $\mathrm{G}$, Delfinado-Baker $\mathrm{M}$ (1983) Observation on mites of the Asian honeybee species (Apis cerana, Apis dorsata, Apis florea). Apidologie 14 (3), 197-204

Mossadegh MS (1990a) Development of Euvarroa sinhai (Acarina: Mesostigmata), a parasitic mite of Apis florea, on Apis mellifera worker brood. Exp Appl Acarol 9, 73-78

Mossadegh MS (1990b) In vitro observations on ontogenesis of the mite, Euvarroa sinhai Delfinado and Baker (Acari, Varroidae), in drone brood cells of the honeybee, Apis mellifera $\mathrm{L}$. J Apic Res 29, 230-232

Mossadegh MS (1991) Geographical distribution, levels of infestation and population density of the mite Euvarroa sinhai Delfinado and Baker (Acarina: Mesostigmata) in Apis florea colonies in Iran. Apidologie 22 (2), 127-134

Mossadegh MS, Komeili BA (1986) Euvarroa sinhai Delfinado and Baker (Acarina: Mesostigmata): a parasitic mite on Apis florea $\mathrm{F}$ in Iran. Am Bee J 126 (10), 684-685

Peng C, Fang $Y, X u S, G e L(1987)$ The resistance mechanism of Apis cerana against the ectoparasitic mite Varroa jacobsoni. J Invertebr Pathol 49, 54-60

Rath W, Delfinado-Baker M (1990) Analysis of Tropilaelaps clareae populations from the debris of Apis dorsata and Apis mellifera in Thailand. In: Proc Int Symp Recent Research on Bee Pathology (Pitter W, ed) Ghent, 8689

Ruttner F, Pourasghar D, Kauhausen D (1985) Die Honigbienen des Iran. II. Apis mellifera meda Skorikow, die Persische Biene. Apidologie 16, 214-264 